\title{
Embodied Listening: Exceeding the Restrictions of Visual Perception
}

\author{
Polly Stanton \\ Masters of Media \\ School of Media and Communication \\ RMIT University \\ 125 Latrobe Street \\ Melbourne, 3000 \\ Australia \\ polly.stanton@rmit.edu.au
}

\begin{abstract}
In an effort to move beyond representational modes of seeing and knowing, in this paper I explore how movement activates listening, and so expands the act of seeing through a process of embodiment and practice. Drawing on fieldwork undertaken for the production of the moving image work 'Between Two Suns', the aim of this paper is to articulate an idea of expanded forms of production that generate performative collaborations and improvisations beyond the camera frame. Through examining the methodological processes undertaken during fieldwork, this paper considers listening as a sensory experience of place that requires movement as a way to relate to other bodies. It contends that through the affective properties of sonic communication, we are able to engage in the world with a perspective that exceeds the restrictions of visual perception; demonstrating how sound draws attention to the entanglements of human and more-than-human forms of life through both movement and gesture. Listening is a form of sonic cognition and it produces a mode of knowledge that is both temporal and ephemeral, through a sensory reading with the world (Voegelin 2014). In this paper, I consider the influence of listening on looking as an embodied experience that requires creative gestures of movement as a way to make contact with otherwise unseen actions and ecologies within environments. By recounting the experiences of practice and process, I will illustrate how listening and performative movement open up a field of possibilities by destabilising the role of the observer through a connection to a larger world.
\end{abstract}

Voegelin, S 2014, Listening to silence and noise: towards a philosophy of sound art, Bloomsbury, London

Sound. Listening. Moving image. Video. Fieldwork. Landscape. Performative. Gesture. Technology. Media.

Sound flows, as wind blows, along irregular, winding paths, and the places it describes are like eddies, formed by the circular movement around rather than a fixed location within. To follow sound, that is to listen, is to wander the same paths. (Ingold 2011, p. 139, emphasis in original)

The breeze brings the drone of the distant city from across the sea while planes score sound-lines in the air above. Noises of motorboats and jet skis float and weave on the summer air around me and I feel overwhelmed by the aural discord. The forests on the island are thickset but I find I am able to easily make my way through the undergrowth by following the numerous small tracks that wind through the trees and demarcate space with a surprising clarity and intelligence in the natural surrounds. The interweaving lines of these tracks become my mapping system as I pursue their meshwork through a foreign landscape, becoming part of a collaborative way-finding system made by unknown movements and beings.

Walking on these predetermined lines that mark their way through the environment like a succession of wanderings, I pass a pocket of quiet that hangs in the air among the sounds of the forest - a punctuating resonance that makes me look. What first appears to be a vine-covered rock face sounds more cavernous. I edge closer, unsure of what is there. It sounds deep and close. I hear the echo of something and I listen again. A water droplet. And then another. I edge along the rock face towards the sound until my body hits a cold patch of air. 
As I move slightly around a curve in the rock I finally see the opening. The entrance to a fort - hidden, its heavy iron door broken away from its hinges. The wind picks up outside and the white noise of the breeze mingles with the thick blanket of damp, centralised quiet. I peek through the open doorway and feel as though I'm looking into a tomb. Inside is still; water covers the floor and from the entrance I can only see one chamber. But at regular intervals droplets fall from the ceiling and ring out through what sound like multiple and interconnected spaces and surfaces. My ears tell me the fort is bigger than it looks.

\section{INTRODUCTION}

These notes, taken from the field research that would become the audio-visual work Between Two Suns, speak of an essential aspect of this paper: how movement activates listening, and so expands the act of seeing through a process of embodiment. The following essay argues that the influence of listening on looking is an embodied experience that requires creative gestures of movement as a way to make contact with otherwise unseen movements and ecologies within environments. Listening is a form of sonic cognition and it produces a mode of knowledge that is both temporal and ephemeral, through a sensory reading with the world (Voegelin 2014). Through examining the methodological processes undertaken for this project, this paper explores listening as a sensory experience of place that requires movement as a way to relate to other bodies. It contends that through the affective properties of sonic communication, we are able to engage in the world with a perspective that exceeds the restrictions of visual perception; the paper demonstrates how sound draws attention to the entanglements of human and more-thanhuman forms of life through both movement and gesture.

Over the course of this paper I illustrate how an embodied engagement with listening opens the field of possibilities when documenting locations with sound and vision. The process of embodied listening is woven diversely throughout this paper, detailing a shift in my practice away from a more removed and controlled disposition of the documenter/observer, and instead towards a more comprehensive and inclusive process of movingimage and sound composition. In this shift, my role as the documenter/observer is destabilised as I become part of a more expansive creative field. The aim of this paper is thus to articulate an idea of expanded forms of production that generate performative collaborations and improvisations beyond the camera frame.

\section{TANGLED PLACES AND FORGOTTEN WORLDS}

Between $T$ wo $S$ uns is a seventeen-minute, single screen sound and moving-image work that documents the landscape of Vallisaari and Kuninkaansaari Island: two disused military outposts located in the grey waters of the Gulf of Finland. Connected by a small land bridge, the islands formed an initial line of defense for the mainland from invading forces in the early 19th century. Colonised twice, once by Sweden and then later by Russia, the islands were handed back to Finland during the Finnish independence in 1917. Because of these histories, the landscape is a tangled web of abandoned dwellings and underground forts that have been uninhabited for decades. Over time, the environment has become a wild and overgrown place, rich in biodiversity as birds, moose, foxes and insects returned to reclaim the forgotten islands.

The landscape of the islands is a haunted place, overflowing with the frontier histories of the past. But beyond this broken assemblage of ruins is an environment surprisingly rugged, vital and teeming with new life. In summertime the islands are a dense web of swamps, thick undergrowth, crumbling foundations and rocky granite outcrops; the unceasing light of the Finnish summer sky creates a feeling of timelessness, with no real beginning or end to the day. Because of these shifting and ambiguous timescales and geographies, the environment is often difficult to navigate: a seemingly constant array of objects and materials blocks the way forward and the sun is always high in the sky. Vision and movement are impaired, so the sound of the surrounding landscape becomes particularly sharp and distinct. It was from this space that the work Between Two Suns was created and an experimental listening methodology - embodied listening - began to take shape.

For over 20 years both islands have been off limits to visitors, marked as a zone of exclusion. The environment was formerly deemed too contaminated with buried artillery, scattered shrapnel and broken buildings to allow people access. But after a slow clean-up, both islands were reopened to the public in spring 2016; and it was on the islands' opening week that I first visited. With little information and with no map, I found myself wandering around in an unknown world of overgrown roads and boarded-up buildings. There were no toilets or clean drinking water, and no signs or maps to help navigate. It felt as though the landscape was uncharted, its previous humanmade boundaries overgrown and forgotten. 


\section{LISTENING AND MOVEMENT}

Over the next three months I traversed the landscape of Vallisaari and Kuninkaansaari by getting lost. Author Rebecca Solnit (2006) considers getting lost to mean crossing a boundary of the unknown - entering a space that allows the world to become larger than one's previous knowledge of it. In this way, my getting lost became a method of seeking, an unknowing space that activated my senses as I searched and discovered the unfamiliar landscape. Leaving the main tourist track, a flat gravel road that looped around a section of the island, I instead followed the myriad animal paths that cut small trails through the thick reindeer moss, walking past swamps and over rocky embankments that edged down towards pebbly beaches. I began to understand the islands' margins, and to experience their valleys and hilltops via these paths that moved through the landscape like small gestures, interconnecting and interweaving with each other almost like a hidden dance.

Listening became a practice of participation and a form of embodied cartography as I became an active part of the landscape, navigating the environment via the trajectories of the trails. Through this natural movement of following paths, I became aware that my listening was operating in tandem with the environment as a co-constructing event. I discovered that I was listening to myself while also in the process of listening to the larger world around me (Berrens 2016). Considering myself from a 'perceiving subject' position (Manning 2014 , p. 16) helped me acknowledge my place in the environments that I traversed. The more listening became a driving methodology and means to understand the islands' boundaries, the more my body became a durational multiplicity, an intuitive space that was able to form relations with other emergent bodies (Manning 2013). Weather also became a signifier of events and movements within the landscape, which further located me in the environment. Ingold writes about 'tactile awareness' (2011, p. 134) and describes how weather and atmospheres invade the body's form. I didn't just hear the environments of the islands; I also heard with them (Ingold 2011).

\section{LISTENING AND MAKING KNOWLEDGE}

Tim Ingold has written much about the creative movement of walking; and as I listened and moved through the temperate forest of the islands, his proposition that the 'movement of walking is a way of knowing' (Vergunst \& Ingold 2005, p. 5) tumbled over in my thoughts. As I had no visual map of the island to draw on, it was the act of listening, and my movements through the landscape, that constructed a creative cartography of sensory experience - an understanding of the size, shape and distance of the land I was inhabiting. By actively participating in listening, I found myself engaging in a learning process of corporeality and emplacement. My listening drew ephemeral sound-lines around and through the island as I slowly amassed knowledge of the environment and allied visual connections to sonic situations. In this way, sound became 'a phenomenon of experience' (Ingold 2011, p. 137) as it presented a field of information beyond the visual plane, which enriched my understanding of both the world and my place within it. Sound penetrated my body and established a sense of communication and participation (Ingold 2000). Unlike the thick undergrowth of the island with its lack of visualspatial views, my body instead resonated as a 'sounding cavity' (Ingold 2000, p. 251), attuned to the world around me.

In studying the ethnographic research of anthropologist Paul Stollar, Ingold writes that vision creates an individualised spectator's gaze, which distances the person from the subject (Ingold 2000, p. 251). Because of the intimate and tactile nature of sound experience, to have attention for knowledge one needs to 'abandon the illusions of vision and yield to the guidance of the ear' (Ingold 2000, p. 252). Perhaps the intimacy and primacy that sound affords for scholars such as Ingold and Stoller lie in sound's abilities to inhabit and move through materials and forms. This embodiment of sound means that listening is a force of potential as much as it is a conscious activity (Farinati \& Firth 2017). Here, I use the word force as an expression of movement and physical action, as opposed to its potentially negative connotations relating to coercion. Force, like sound, is everywhere. Force reminds us that 'life is neither in the individual nor outside it but surpasses it while accompanying it' (Manning 2013, p. 17). Force is active and gestural. Like listening, it is part of an internal resonance of movement and attention within the body that relates to other corresponding bodies. And so, in this way, listening becomes a generative force that gathers sounds to make meaning.

\section{MOVEMENT, FORCE AND MINOR LISTENING GESTURES}

A gesture is a physical force of movement, a shift that expresses feelings and thoughts. It is a creative act, a reaching out. Listening to the landscapes of Vallisaari and Kuninkaansaari, I began to imagine listening as a subtle movement - or, more specifically, as a minor gesture. Inspired by Gilles Deleuze and Félix Guattari's work on minor literature, minor theory utilises notions of displacement, spatiality, and temporality to create spaces of in-betweenness that reveal new productions of knowledge outside of normative 
forms. For dancer and scholar Erin Manning, the minor gesture is never known in advance. Instead it is an affective and spontaneous expression of creative force that advances understanding through a process of movement, which then opens up potential to variation from within the experience itself (Manning 2016). To work with the minor is to make conscious experiences of pragmatic and speculative flux, the minor's value being 'as ephemeral as it is mobile' (Manning 2016, p. 2).

To think through listening as a minor gesture is to consider the practice of listening as a spontaneous creative movement that responds to events. These events can be sound-based, but by also exploring the ability to listen as a gesture, listening can be augmented towards the more-than sonic realm and non-cochlear events. Before I continue with such thoughts, I want to consider more fully what constitutes landscape, what it contains and how it can be experienced as a creative act in and of itself.

\section{LANDSCAPES AS EVENT: TIME AND MUTABILITY}

Moving through the connected landscapes of Vallisaari and Kuninkaansaari was a process of making meaning through interlinking events. With no map and no prior experience of the environment, I lost my usual understandings of scale and time, and I often became disoriented and unknowingly circled back on myself. As I followed the winding paths, my perception of the environment became linked to acts of remembrance (Ingold 1993) as I tried to piece together familiar sounds and sites as a process of situating. Slowly an ephemeral map of the islands began to take form. I soon realised that the deep city hum of Helsinki came from the north side of Vallisaari while the much quieter Kuninkaansaari faced towards the Finnish gulf and faraway Estonia. Depending on what I could hear became an essential way to understand where I was located within the environment. The islands are rocky and hilly and, in many areas, covered in thick forest and dense scrub, which made seeing beyond a few metres difficult. As I followed the paths, which moved like small currents whirling around the landscape, I found myself relying on sound as a guide to compensate for what I couldn't see.

Through this simple process of listening I began to notice how the experience of these sonic places affected me far beyond the limitations of my eyes. The landscape that I touched and moved through acted as a sonic conduit. The detailed sounds of the rock shoreline, the thick bird song of the birch forests, the vibrational insect hum of the swamps and the whistling outcrops of the hill tops became known to me through an aural experience of place that affected my whole body, beyond just the physical location of my ears. Through these experiences I began to understand how being situated in landscape allows the environment to become 'a part of us, just as we are a part of it' (Ingold 2000, p. 191). Landscape moderated the sound while also affecting my listening - my body became both a sounding object and a cartographic instrument as I navigated my way around the islands.

In his book The Perception of the Environment, Tim Ingold writes that the concept of landscape puts an emphasis on form, and that the forms of the body and landscape are complementary 'through the processual unfolding of a total field of relations' (Ingold 2000, p. 193) - a field that could also be considered a process of embodiment. Ingold distinguishes embodiment as movement within the landscape, proposing that looking and listening are not separate activities, but indeed constitute one integrated movement as a response to the environment (Ingold 2011). Landscapes are deeply reciprocal. 'To see is to be seen; to touch is to be touched' (Benediktsson \& Lund 2010, p. 7) and similarly, to listen is to be listened to. To listen to a landscape is to listen to oneself: to take time and to be known through a process of establishing one's body in the environment. Considering the landscape from this point of relational exchange, I began to question how I could document the places I moved through without removing myself continually from this field of exchange through the externalising nature of the camera lens and the microphone.

\section{LANDSCAPE AS TASKSCAPE}

My focus during this fieldwork was to move, to understand and to document. As I walked and listened through the landscape I also carried with me a backpack full of sound and video equipment. As I scrambled my way through dense undergrowth, rarely able to view a horizon line, my senses became focused on smallness and closeness: the immediacy of my surroundings. Listening to the activity of each place encouraged me to be more intuitive to subtle happenings and movements. In this way the work Between Two Suns became a call and response of looking and listening - what I heard would show me something visual, and what I saw would in turn direct me to a sound. At each spontaneous stop I would sit and listen first, as a way to focus on the place and to allow the environment to become accustomed to my presence. I would then open my bag and pull out either my camera or recorder, depending on what I had seen or heard - the sound of distant gunfire or wind through the trees; a spider web in the sun; a fallen tree. From this vantage point of listening and watching, the landscape started to resemble what Ingold (2000) refers to as the taskscape - the 
embodied and reciprocal form of landscape. The taskscape exists as interactivity (Ingold 2000). It is a conception of 'rhythmic harmonisation and mutual attention' (Ingold 2000, p. 199). Taskscapes are also directed towards listening as a force. They are a congealed translation of a landscape based in activity, the limits of which are the auditory world (Ingold 2000). Listening is, then, an essential way to access the taskscape. As it is born from action, movement and reciprocity, so too is it intrinsically related to 'the agent who watches and listens' (Ingold 2000, p. 199).

As I became part of the taskscape, this agency extended to my recorder and camera. As a means to further embed these technologies into the taskscape, I began to attach my microphones to trees, or I positioned them on the ground in among reeds, grasses and rocks. In a similar fashion, I often used found objects as a way to hold and point my camera in certain directions. Ants crawled across my lens and my microphones swung back and forth with the leaves and tree limbs in the breeze - the technologies' capability to document was directly affected by the total movement of becoming in the environment. The more I experimented with these placements, the more I began to see the action of installing the microphones in the environment as a minor gesture. These gestures were operational (Manning 2016, p. $6)$, situated within the larger becoming of the taskscape. Each minor gesture of microphone or camera placement was precarious and improvisational, a direct response to whatever was revealed to me through the activity of the surrounding environment. Opening up operational intervals, these gestures of placement reoriented experience by punctuating the event in question through moving the event in 'new and divergent directions' (Manning 2016, p. 2). Manning states that the event and minor gesture are always cocompositional. They take part in the larger taskscape of movement that is both speculative and pragmatic. By literally placing my equipment within the taskscape through a spontaneous gesturing based on the environment's inherent movement, my equipment and I became autonomous and active members of the taskscape's creative force.

\section{FURTHER MICROPHONE GESTURES AND CAMERA STRATEGIES}

As a way to continue these experiments, I made a decision to limit my equipment choices by choosing to use a spaced pair of small omnidirectional microphones, and a fixed $18 \mathrm{~mm}$ wide-angle lens for my camera. This was to impose a compositional constraint that both limited and simplified how I documented the environment, which would in turn force me to be more immediate with how I responded to events and happenings.

Omnidirectional microphones receive signals from all directions, unlike cardioids, which have a more focused pickup pattern. Correspondingly, a fixed wide-angle lens also lacks the ability to focus on one area, instead capturing a more located and generalised visual scene. Matching the way the microphones and camera captured the environment was my attempt to democratise my audiovisual equipment and lessen the impact filming had on how I listened and moved. These equipment choices also forced me to get closer to what I was recording if I wanted to focus on a sound or visual moment, involving me more fully in the taskscape at hand.

Often this meant I had to crawl and climb to get closer to objects instead being able to stand back from a distance and zoom in with my lens or point my microphones in a specific direction. I was less in control and more at the whims of the terrain and weather; the taskscape had a compelling effect on my movements, direction and documentation. These equipment choices also meant I listened more to the whole assemblage of the environment, rather than just one aspect of the auditory scene. Having my freedom curtailed by my usage of camera and sound equipment opened up a vibrant space by allowing a larger transmission force - the taskscape - to direct what could and couldn't be captured. This transmission is an essential part of working with audio-visual media in the landscape, and provides an interesting association with the aforementioned minor gesture: to point a microphone or camera in a particular direction is to make a minor gesture in response to other minor gestures. It is a transmission of motion and action. It is not an attempt to record an idea of reality, but instead it assembles a new creative event through a dialogue with other movements, beings and forms.

\section{WALKING AND LINE TRACING}

Attending to landscape via the process of listening helped me create a sensory cartography of both islands through a participation in movement, which was facilitated through the activity of walking. In social anthropological circles, walking as a mode of place making has been gaining momentum as a multisensory research activity that creates forms of embodied knowledge (Pink 2007, p. 244). Sound walks are a related geographical practice that involves moving through specific locations with a particular focus on the sonic environment. These audio walks are increasingly used both as a way to personalise the wayfaring experience and as a means to encounter environments through the internalized process of listening. But I argue that 
walking-and-listening goes beyond a navigation device; it is a more process-based and abstract experience that actively takes part in the cocreation of landscape. As I walked, pushed, tripped, jumped and crawled my way through the landscape, knowledge of my surroundings was gathered from an assemblage of connections and variable points of contact. Approached in this way, listening and walking became a lively and messy encounter with the sensory world, which created a transition of knowledge through both the act of encounter and the gathering of documentation.

The tangle of ruins that were scattered around the islands created a maze of transformed spaces. Broken walls, open doorways and collapsed roofs jutted out of the landscape like shipwrecks. The trails I followed had already manoeuvred a wellworn groove around each encountered object, and because of this, I was never confounded or blocked in the landscape; instead I was able to travel through sites with a logical ease despite having no map, thanks to the paths that snaked out before me like signals. When speaking of ruins in his text Ways of Walking, Ingold speaks of the difficulties of walking: the ground can give way, and whatever you cling to for support might also come crashing down at any moment. Getting around unknown sites, then, frequently defers to copying the movements of others, and in doing so allows one to perceive the environment in more-than-human ways (Ingold 2008). From this aspect, landscape becomes a mediated form of encounter: a place of becoming and a non-hierarchical meshwork where all bodies are situated.

Conceiving landscape from this perspective highlights the body as a receptor that makes meaning from the world. The body becomes a 'participative listening tool' (Berrens 2016, p. 80) of movement and action beyond the capacity of the ear. The act of listening in the world is a gesture of openness, of a more-than-me experience. It operates in the margins of not knowing but seeks to connect, to understand and to make meaning. It is a form of knowledge making, 'defining and keeping in touch with our sensuous body, our emotions and connecting past and present into the moment of listening' (Berrens 2016, p. 80). Thus, embodied listening allows us to engage a process of sensory insight that restores itself to the forefront of our relationship to the world (Berrens 2016).

\section{SUMMARY}

This essay primarily articulates an expansive approach towards working with sound and the moving image in the field, including a spectrum of engagements ranging from the jumbled experience of walking with ruins to the sensory and instinctive positioning of microphone and camera placement within the environment. As such, the paper is structured by, and actively presents, a field of sonic and visual possibilities in which listening and its effects are developed and interrogated. In doing so, it explores an experimental approach to both fieldwork and art practice, situating the process of listening as a site-responsive experience made up of an ever-changing weather world, full of moments of transformation and fluctuating scales of difference.

Listening is therefore a provocation to find ways to engage in a particular kind of audio-visual practice that is situated and embodied. Through identifying several such creative principles, this paper contributes a series of possible approaches and methodologies, which moving-image artists, documentary filmmakers, photographers, ethnographers and geographers may appropriate and develop by exploring and affirming openness, process, and the provisional. This paper then represents a staging for attempting meshworks between an assemblage of parts - expanding notions but also modes of perception and production. It is the kind of space that encourages us to become what Ingold (2011, p. xii) describes as someone who moves, knows and is observant - a state of being alive to the world.

\section{REFERENCES}

Benediktsson, K \& Lund, AK 2010, Conversations with landscape, Ashgate, Farnham, Surrey

Farinati, L \& Firth, C (eds) 2017, The force of listening, Errant Bodies Press, Berlin

Gallagher, M, Kanngieser, A \& Prior, J 2017, 'Listening to geographies: landscape, affect and geotechnologies', Progress in Human Geography, vol. 41, no. 5, pp. 618-637.

Ingold, T 1993, 'The temporality of landscape', World Archaeology, vol. 25, no. 2, pp. 152-174.

Ingold, T 2000, The perception of the environment: essays on I ivelihood, dw elling ands kill, Routledge, London.

Ingold, T 2001, 'From the transmission of representations to the education of attention', in $\mathrm{H}$. Whitehouse (ed.), The deb ated $m$ ind: evolutionary ps ychology $v$ ersus ethnography, Berg, Oxford, pp. 113-153.

Ingold, T 2010, 'Footprints through the weatherworld: walking, breathing, knowing', Journal of the Royal Anthropological Institute, vol. 16, pp, 121-139.

Ingold, T 2011, Being alive: es says on movement, knowledge and de scription, Routledge, New York. 
Janowski, M \& Ingold, T (eds) 2012, Imagining landscapes: pas $t$, present and $f$ uture, Ashgate, Surrey.

Manning, E 2009, Relationscapes: movement, art, philosophy, MIT Press, Cambridge.

Manning, E 2013, Always $m$ ore $t$ han one: individuation's dance, Duke University Press, Durham.

Manning, E 2014, 'Wondering the world directly - or, how movement outruns the subject', Body a nd Society, vol. 20, no. 3-4, pp. 162-188.

Manning, E 2016, The $m$ inorge sture, Duke University Press, Durham.

Solnit, R 2006, A field guide to getting lost, Penguin Books, London

Pink, S 2007, 'Walking with video', Visual Studies, vol. 22, no. 3, pp 240-252.

Pink, S 2015, Doing sensory et hnography, 2nd edition, Sage, London

Vergunst, J \& Ingold, T (eds) 2008, Ways of walking: ethnography and pr actice on foot, Routledge, London.

Voegelin, S 2014, Listening to s ilence and noi se: towards a ph ilosophy of sound art, Bloomsbury, London

Berrens, K 2016, 'An emotional cartography of resonance', Emotion, Space and Society, vol. 20, pp. 75-81. 